\title{
ORGANOPHOSPHORUS PESTICIDES TOXICITY ON BRINE SHRIMP, ARTEMIA
}

\author{
Jawahar Ali A ${ }^{1}$, A. Jamal Mohamed ${ }^{1}$, M.S. Arun Kumar'1, B. Akbar John² \\ ${ }^{1}$ Unit of Aquaculture and Aquatic Toxicology, P.G \& Research Department of Zoology, The New College, Chennai-14, India. \\ ${ }^{2}$ INOCEM Research Station (IRS), Kulliyyah of Science, International Islamic University Malaysia (IIUM), Kuantan, Pahang, Malaysia \\ *Corresponding author Email: akbarjohn50@gmail.com
}

\section{ARTICLE DETAILS}

\section{Article History:}

Received 12 November 2017 Accepted 12 December 2017 Available online 1 January 2018

Keywords:

Artemia, Glyphosate, Toxicity tests.

\section{ABSTRACT}

Present investigation discusses the toxic effects of two organophosphorus pesticides (Malathion) and (Glyphosate) on brine shrimp, Artemia in static acute toxicity tests (24hr and $48 \mathrm{hr}$ ). Toxicity tests were performed at a temperature of $27 \pm 1^{\circ} \mathrm{C}$ with a photoperiod of $12 \mathrm{~h}$ light and $12 \mathrm{~h}$ dark. Ten healthy nauplii were exposed to five different concentrations of Malathion $(10,20,40,60$ and $80 \mathrm{ppm})$ and Glyphosate $(0.01,0.02,0.03,0.04$ and 0.05 $\mathrm{ppm}$ ) along with a control group. Finney's Probit analysis was used to determine the $24 \mathrm{~h} / 48 \mathrm{~h} \mathrm{LC}_{50}$ values and were found to be 58.3 and $17.3 \mathrm{ppm}, 0.028$ and $0.019 \mathrm{ppm}$ for Malathion and Glyphosate, respectively. Of the two pesticides tested Glyphosate was found to be significantly more toxic to Artemia nauplii than that of Malathion (P < $0.05)$.

\section{INTRODUCTION}

In recent years, synthetic pesticides are extensively being used to ensure crop yields, quality, and the variety and quantities of these substances accidently discharged into aquatic ecosystems which in term lead to various adverse consequences on the non-target organism [1]. Organophosphorus pesticides (OPs) have largely replaced organochlorine compounds in the intensive agricultural activities because of their less persistent life and easy detoxification in animal tissues [2].

The mode of action of Ops arises by inhibiting the enzyme acetylcholinesterase (AChE. E.C. 3.1.1.7), which is responsible for conducting the nerve impulse during neurotransmission as well as plays a vital role in the development of neurons and network formation in central nervous system [3-6]. Moreover, Ops also act as an endocrine disruptor and known to produce genotoxic, immunotoxic effects and oxidative stress which is incapable of increasing the levels of reactive oxygen species (ROS) in aquatic organisms [7-13].

Presently, organophosphates are considered to be highly toxic to many aquatic organisms [14-17,13]. It should be noted that, over the last two decades, the brine shrimp Artemia has gained popularity as test organism for short term bioassays because of its ease culture, short generation time, cosmopolitan in distribution and its commercial availability as resting eggs and hence, been used as live food for finfish and shellfish in aquaculture [18-25]. This cyst was suggested as an attractive alternative to standard invertebrate stock cultures, since test animals can be hatched synchronously [26-29]. Like other organisms, Artemia also tend to bioaccumulate the toxicants and subsequently transferred them to higher tropic levels in the food chain. Therefore, it is necessary to know the relationship between Artemia and its tolerance range of various pollutants, so that the cultures can be used more safely and effectively $[30,31]$. In the present study, we investigated the toxic effect of two highest market selling organophosphorus pesticides namely Malathion and Glyphosate on Artemia.

\section{MATERIAL AND METHODS}

\subsection{Chemicals}

Commercial grade pesticides of Malathion, (Milathion 50\% EC, manufactured by Insecticides India Private Limited New Delhi) and Glyphosate (Roundup 41\% SL, manufactured by Monsanto India Private
Limited New Delhi) were procured from Agrochemical Store at Vellore, Tamil Nadu, India. Analytical grade $\mathrm{NaCl}, \mathrm{Na}_{2} \mathrm{SO}_{4}, \mathrm{KCl}, \mathrm{KBr}, \mathrm{Na}_{2} \mathrm{~B}_{4} \mathrm{O}_{7} .10 \mathrm{H}_{2} \mathrm{O}$, $\mathrm{MgCl}_{2} .6 \mathrm{H}_{2} \mathrm{O}, \mathrm{CaCl}_{2} .2 \mathrm{H}_{2} \mathrm{O}, \mathrm{SrCl}_{2} .6 \mathrm{H}_{2} \mathrm{O}$ and $\mathrm{NaHCO}_{3}$ were purchased from Himedia India for preparation of synthetic seawater.

\subsection{Test organisms}

Artemia resting eggs (cysts) were collected from the salt pans of Veppalodai, Tuticorin, Tamil Nadu, India. Cysts were hatched into nauplii by following the standard ARC procedures (Artemia Reference Centre, State University of Ghent, Belgium). About $10 \mathrm{~g}$ of the Artemia cysts were incubated in a cylindroconical glass tube containing $100 \mathrm{ml}$ of synthetic seawater (36ppt) which was prepared by dissolving $21.03 \mathrm{~g}$ of $\mathrm{NaCl}, 3.52$ $\mathrm{g}$ of $\mathrm{Na}_{2} \mathrm{SO}_{4}, 0.61 \mathrm{~g}$ of $\mathrm{KCl}, 0.088$ of $\mathrm{KBr}, 0.034 \mathrm{~g}$ of $\mathrm{Na}_{2} \mathrm{~B}_{4} \mathrm{O}_{7} .10 \mathrm{H}_{2} \mathrm{O}, 9.50 \mathrm{~g}$ of $\mathrm{MgCl}_{2} \cdot 6 \mathrm{H}_{2} \mathrm{O}, 1.32 \mathrm{~g}$ of $\mathrm{CaCl}_{2} \cdot 2 \mathrm{H}_{2} \mathrm{O}, 0.02 \mathrm{~g}$ of $\mathrm{SrCl}_{2} \cdot 6 \mathrm{H}_{2} \mathrm{O}$ and $0.17 \mathrm{~g}$ of $\mathrm{NaHCO}_{3}$ per liter of MILLI-Q water. Temperature was maintained at $28 \pm 1^{\circ} \mathrm{C}$ and the $\mathrm{pH}$ was adjusted to 8.3 throughout hatching and the glass container was supplied with strong aeration. The light (2000 lux) was provided by a fluorescent lamp placed near the hatching vessels. The photoperiod was maintained at 16: 8D/L. After $24 \mathrm{hr}$ of incubation, the free swimming nauplii were attracted towards the light source (phototactic behavior) and randomly collected for toxicity tests.

\subsection{Static acute toxicity test}

Static acute toxicity tests were conducted in $250 \mathrm{ml}$ test vessels at a temperature of $27 \pm 1^{\circ} \mathrm{C}$ with a photoperiod of $12 \mathrm{~h}$ light and $12 \mathrm{~h}$ dark. Stock solutions of Malathion and Glyphosate were prepared in synthetic seawater and its dilutions were made as per the requirements. Based on the range finding tests, five different concentrations of each pesticide, 10 , $20,40,60$ and $80 \mathrm{ppm}$, respectively for Malathion and 0.01, 0.02, 0.03, 0.04 and $0.05 \mathrm{ppm}$, respectively for Glyphosate were selected; ten nauplii per vessel were allowed in $100 \mathrm{ml}$ of test solutions. Experiments were carried out in triplicates. The nauplii were not fed during the exposure period. The mortality of the nauplius was checked after specific exposure periods namely 24 and $48 \mathrm{hrs}$. At the end of each observation period, the number of dead animals were counted under dissection microscope and discarded.

\subsection{Statistical Analysis}

Data on percentage mortality were used to calculate the 24 and $48 \mathrm{hr} \mathrm{LC}_{50}$ values by Probit analysis method [32]. Analysis of variances (ANOVA) was used to compare the mortality (\%) values of Malathion and Glyphosate to 
Artemia nauplii after 24 and 48 hrs using SPSS ver.13.0 IBM software [33].

\section{RESULTS}

The 24 and $48 \mathrm{hrs} \mathrm{LC}_{50}$ values for Artemia nauplii exposed to Malathion and Glyphosate were depicted in Table 1 . The 24 and $48 \mathrm{hr} \mathrm{LC}_{50}$ values of Malathion to Artemia nauplii were 58.3 and $17.3 \mathrm{ppm}$, respectively and those for glyphosate were 0.028 and $0.019 \mathrm{ppm}$, respectively.

Table 1: The $\mathrm{LC}_{50}$ values of Malathion and Glyphosate to Artemia nauplii after 24 and $48 \mathrm{hrs}$ exposure

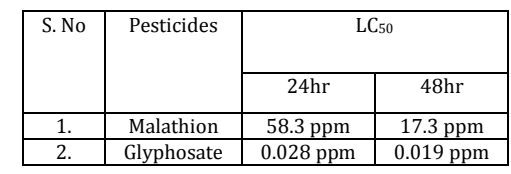

An overall significant effect of Malathion and Glyphosate on the mortality of Artemia nauplii was revealed ( $<<0.05$; Tables $2 \& 3)$. Different concentrations of Malathion and Glyphosate also had significant effect ( $\mathrm{P}$ $<0.05)$.

Table 2: Comparative toxicity (mortality \%) of Malathion and Glyphosate to Artemia nauplii after $24 \mathrm{hrs}$ exposure (ANOVA)

\begin{tabular}{|c|c|c|c|c|c|c|}
\hline Variable & Source & $\begin{array}{c}\text { Sum of } \\
\text { Squares } \\
\text { (mortality } \\
\text { \%) }\end{array}$ & df & $\begin{array}{c}\text { Mean } \\
\text { square }\end{array}$ & F & Sig. \\
\hline $\begin{array}{c}\text { Malathion } \\
\text { Vs } \\
\begin{array}{c}\text { Artemia } \\
\text { nauplii }\end{array}\end{array}$ & $\begin{array}{c}\text { Between } \\
\text { groups }\end{array}$ & 63.067 & 4 & 15.767 & 236.50 & $.000^{*}$ \\
\cline { 2 - 7 } & $\begin{array}{c}\text { Within } \\
\text { groups }\end{array}$ & 0.667 & 10 & 0.067 & -- & - \\
\cline { 2 - 7 } & \begin{tabular}{c} 
Total \\
\cline { 2 - 7 }
\end{tabular} & 63.733 & 14 & -- & -- & -- \\
\hline \multirow{2}{*}{$\begin{array}{c}\text { Glyphosate } \\
\text { Vrtemia } \\
\text { nauplii }\end{array}$} & $\begin{array}{c}\text { Between } \\
\text { groups }\end{array}$ & 71.067 & 4 & 17.767 & 133.250 & $.000^{*}$ \\
\cline { 2 - 7 } & $\begin{array}{c}\text { Within } \\
\text { groups }\end{array}$ & 1.333 & 10 & 0.133 & -- & -- \\
\cline { 2 - 7 } & Total & 72.400 & 14 & -- & -- & - \\
\hline
\end{tabular}

Note: *Significant level is expressed at $95 \%$ confident interval $(\mathrm{P}<0.05)$

Table 3: Comparative toxicity (mortality \%) of Malathion and Glyphosate to Artemia nauplii after $48 \mathrm{hrs}$ exposure (ANOVA)

\begin{tabular}{|c|c|c|c|c|c|c|}
\hline Variable & Source & $\begin{array}{c}\text { Sum of } \\
\text { Squares } \\
\text { (mortality \%) }\end{array}$ & df & $\begin{array}{c}\text { Mean } \\
\text { square }\end{array}$ & F & Sig. \\
\hline $\begin{array}{c}\text { Malathion } \\
\text { Vs } \\
\begin{array}{c}\text { Artemia } \\
\text { nauplii }\end{array}\end{array}$ & $\begin{array}{c}\text { Between } \\
\text { groups }\end{array}$ & 71.600 & 4 & 17.900 & 134.250 & $.000^{*}$ \\
\cline { 2 - 7 } & $\begin{array}{c}\text { Within } \\
\text { groups }\end{array}$ & 1.333 & 10 & 0.133 & -- & - \\
\cline { 2 - 7 } & Total & 72.933 & 14 & -- & -- & -- \\
\hline
\end{tabular}

\begin{tabular}{|c|c|c|c|c|c|c|}
\hline $\begin{array}{c}\text { Glyphosate } \\
\text { Vs }\end{array}$ & $\begin{array}{c}\text { Between } \\
\text { groups }\end{array}$ & 103.067 & 4 & 25.767 & 193.250 & $.000 *$ \\
\hline \multirow[t]{2}{*}{$\begin{array}{c}\text { Artemia } \\
\text { nauplii }\end{array}$} & $\begin{array}{l}\text { Within } \\
\text { groups }\end{array}$ & 1.333 & 10 & 0.133 & -- & -- \\
\hline & Total & 104.400 & 14 & -- & -- & -- \\
\hline
\end{tabular}

Note: *Significant level is expressed at $95 \%$ confident interval $(\mathrm{P}<0.05)$

\section{DISCUSSION}

The present study was aimed to evaluate the short-term toxicity of the two highest market selling organophosphorus pesticides namely, Malathion and Glyphosate on 24hr old (instar I) larvae of Aretmia. The brine shrimp Artemia has many advantages as a marine test organism and widely used for the evaluation of different types of contaminants including pesticides and heavy metals $[34,27,35-38,28,39]$. It also a play a main food supply for the millions of shorebirds, and also used as major food source in marine and fresh water aquaculture $[38,40]$.

The results showed differences in sensitivity of Artemia against two pesticides namely Malathion and Glyphosate (Table 1), the 24 and $48 \mathrm{hr}$ $\mathrm{LC}_{50}$ values of Malathion on Artemia nauplii were 58.3 and $17.3 \mathrm{ppm}$, respectively. In an earlier study, a group researcher reported $24 \mathrm{hr} \mathrm{LC}_{50}$ value of $81.5 \mathrm{ppm}$ for Malathion to the freshwater anostracan, Streptocephalus proboscidius nauplii [41]. A group of scientists have found $24 \mathrm{hr} \mathrm{LC} 50$ value of $67.7 \mathrm{ppm}$ for Malathion to S. sudanicus nauplii [42]. However, some of them reported $24 \mathrm{hr} \mathrm{LC}_{50}$ value of $6.4 \mathrm{ppm}$ for Malathion to $S$. proboscidius nauplii [43]. Likewise, a researcher observed a $24 \mathrm{hr} \mathrm{LC}_{50}$ value of $24.5 \mathrm{ppm}$ for Malathion to Branchinecta sandiegonensis [44]. Table 4 summarizes the toxicity of Malathion and Glyphosate used in earlier studies as well as in the present study to different branchiopods.

Table 4: Toxicity of $\left(\mathrm{LC}_{50}\right)$ of Malathion and Glyphosate to branchiopods

\begin{tabular}{|c|c|c|c|c|}
\hline Pesticides & Test organisms & $\begin{array}{l}\text { Hours } \\
\left(\mathrm{LC}_{50}\right)\end{array}$ & Values & Source \\
\hline Malathion & $\begin{array}{l}\text { S. proboscidius } \\
24 \mathrm{hr} \text { nauplii }\end{array}$ & $24 \mathrm{hr} \mathrm{LC}_{50}$ & 81.5 & Crisinel et al. (1994) \\
\hline Malathion & $\begin{array}{l}\text { S. Sudanicus } \\
\text { 24hr nauplii }\end{array}$ & $48 \mathrm{hr} \mathrm{LC}_{50}$ & 67.7 & Lahr et al. (2001) \\
\hline Malathion & $\begin{array}{l}\text { S. proboscidius } \\
24 \mathrm{hr} \text { nauplii }\end{array}$ & $24 \mathrm{hr} \mathrm{LC}_{50}$ & 6.4 & Verschueren (2001) \\
\hline Malathion & $\begin{array}{l}\text { B. sandiegonensis } \\
24 \mathrm{hr} \text { nauplii }\end{array}$ & $24 \mathrm{hr} \mathrm{LC}_{50}$ & 24.5 & Ripley et al. (2003) \\
\hline Malathion & $\begin{array}{l}\text { S. dichotomus } 24 \mathrm{hr} \\
\text { nauplii }\end{array}$ & $24 \mathrm{hr} \mathrm{LC}_{50}$ & 14.1 & $\begin{array}{l}\text { Arun Kumar and } \\
\text { Jawahar Ali }(2014 b)\end{array}$ \\
\hline Malathion & $\begin{array}{l}\text { S. dichotomus } 24 \mathrm{hr} \\
\text { nauplii }\end{array}$ & $48 \mathrm{hr} \mathrm{LC}_{50}$ & 12.3 & $\begin{array}{c}\text { Arun Kumar and } \\
\text { Jawahar Ali (2014b) }\end{array}$ \\
\hline Malathion & $\begin{array}{l}\text { Artemia } 24 \mathrm{hr} \\
\quad \text { nauplii }\end{array}$ & $48 \mathrm{hr} \mathrm{LC}_{50}$ & 1.00 & Sidharta (1997) \\
\hline Malathion & C. dubia & $24 \mathrm{hr} \mathrm{LC}_{50}$ & 0.00318 & $\begin{array}{c}\text { Nelson and Roline } \\
\text { (1998) }\end{array}$ \\
\hline Malathion & D. magna & $48 \mathrm{hr} \mathrm{LC}_{50}$ & 0.003 & $\begin{array}{l}\text { Rassoulzadegan and } \\
\text { Akyurtalkli (2002) }\end{array}$ \\
\hline Malathion & $\begin{array}{l}\text { Artemia } 24 \mathrm{hr} \\
\text { nauplii }\end{array}$ & $24 \mathrm{hr} \mathrm{LC}_{50}$ & 58.3 & Present study \\
\hline Malathion & $\begin{array}{l}\text { Artemia } 24 \mathrm{hr} \\
\quad \text { nauplii }\end{array}$ & $48 \mathrm{hr} \mathrm{LC}_{50}$ & 17.3 & Present study \\
\hline Glyphosate & $\begin{array}{l}\text { T. platyurus } 24 \mathrm{hr} \\
\text { nauplii }\end{array}$ & $24 \mathrm{hr} \mathrm{LC}_{50}$ & 0.35 & Foctman et al. (2000) \\
\hline Glyphosate & $\begin{array}{l}\text { B. sandiegonensis } \\
24 \mathrm{hr} \text { nauplii }\end{array}$ & $24 \mathrm{hr} \mathrm{LC}_{50}$ & 0.0118 & Ripley et al. (2003) \\
\hline Glyphosate & $\begin{array}{l}\text { B. thailandensis } \\
24 \mathrm{hr} \text { nauplii }\end{array}$ & $24 \mathrm{hr} \mathrm{LC}_{50}$ & 0.319 & $\begin{array}{c}\text { Boonsoong and } \\
\text { Bullangpoti (2012) }\end{array}$ \\
\hline
\end{tabular}




\begin{tabular}{|c|c|c|c|c|}
\hline & & & & \\
\hline Glyphosate & $\begin{array}{c}\text { S. dichotomus } 24 \mathrm{hr} \\
\text { nauplii }\end{array}$ & $24 \mathrm{hr} \mathrm{LC}_{50}$ & 0.026 & $\begin{array}{c}\text { Arun Kumar and } \\
\text { Jawahar Ali (2014b) }\end{array}$ \\
\hline Glyphosate & $\begin{array}{c}\text { S. dichotomus } 24 \mathrm{hr} \\
\text { nauplii }\end{array}$ & $48 \mathrm{hr} \mathrm{LC} 50$ & 0.014 & $\begin{array}{c}\text { Arun Kumar and } \\
\text { Jawahar Ali (2014b) }\end{array}$ \\
\hline Glyphosate & D. magna & $48 \mathrm{hr} \mathrm{LC} 50$ & 42 & Alberdi et al. (1996) \\
\hline Glyphosate & D. magna & $48 \mathrm{hr} \mathrm{LC}_{50}$ & 250 & Raipulis et al. (2009) \\
\hline Glyphosate & $\begin{array}{c}\text { Artemia } 24 \mathrm{hrs} \\
\text { nauplii }\end{array}$ & $24 \mathrm{hr} \mathrm{LC} 50$ & 0.028 & Present study \\
\hline Glyphosate & $\begin{array}{c}\text { Artemia } 24 \mathrm{hrs} \\
\text { nauplii }\end{array}$ & $48 \mathrm{hr} \mathrm{LC}_{50}$ & 0.019 & Present study \\
\hline
\end{tabular}

(Crustacea: Anostraca). International Journal of Bioassays, 3 (09), 33073312.

[3] Maxwell, D.M., Brecht, K.M., Koplovitz, I., Sweeney, R.E. 2006 Acetylcholinesterase inhibition: does it explain the toxicity of organophosphorus compounds? Archives of Toxicology, 80, 756-760.

[4] Boelsterli, U. 2007. Mechanistic Toxicology: The Molecular Basis of How Chemicals Disrupt Biological Targets, 2nd, ed.; CRC Press - Taylor \& Francis Group, LLC: Boca Rato.

[5] Paraoanu, L.E., Layer, P.G. 2008. Acetylcholinesterase in cell adhesion, neurite growth and network formation. FEBS J. 275 (4), 618624.

[6] Arun Kumar, M.S., Jawahar, A.A. 2013. Toxic impacts of two Organophosphorus pesticides on the acetylcholinesterase activity and biochemical composition of freshwater fairy shrimp Streptocephalus dichotomus. International Journal of Pharma and Bio Sciences, 4 (2), 966 972.

According to a study, the $48 \mathrm{hr} \mathrm{LC}_{50}$ value of Malathion (Technical grade) to Artemia salina was $1.00 \mathrm{ppm}$ [45]. At the same time, two researchers observed $48 \mathrm{hrs} \mathrm{LC}_{50}$ value of was $12.3 \mathrm{ppm}$ to $S$. dichotomus, which is lower than the value observed in the present study [2]. However, in other study, they documented a $24 \mathrm{hr} \quad \mathrm{LC}_{50}$ value of $0.00318 \mathrm{ppm}$ for Ceriodaphnia dubia [46]. The $48 \mathrm{hrs} \mathrm{LC}_{50}$ values of technical and commercial grades of Malathion to D. magna were $0.028 \mathrm{ppm}$ and 0.003 ppm, respectively [47].

As shown in Table 1, the 24 and $48 \mathrm{hr} \mathrm{LC}_{50}$ values of Glyphosate to Artemia nauplii were 0.028 and $0.019 \mathrm{ppm}$, respectively. From these results it is obvious that Glyphosate was significantly more toxic to Artemia nauplii than Malathion $(\mathrm{P}<0.05)$. A group of researchers has demonstrated that the $24 \mathrm{hr} \mathrm{LC}_{50}$ value for Glyphosate on anostracan, Thamanocephalus Platyurus was $0.35 \mathrm{ppm}$ [48]. However, some of them observed $24 \mathrm{hr} \mathrm{LC}_{50}$ value of $0.0118 \mathrm{ppm}$ for Glyphosate to B. Sandiegonensis [44]. Whereas reported $24 \mathrm{hr} \mathrm{LC}_{50}$ value of $0.319 \mathrm{ppm}$ for Glyphosate to B. Thailandensis nauplii. Fairy shrimp, S. dichotomus exposed to Glyphosate showed an $\mathrm{LC}_{50}$ of $0.014 \mathrm{ppm}$, which is lower than the present study of $0.019 \mathrm{ppm}$ for brine shrimp, Artemia in 48 hours [2]. A scientist observed that Artemia franciscana exposed to Glyphosate and Zinc in combination produced an increase in lethality compared to shrimp exposed only to Glyphosate and Zinc separately [39].

According to some study, the $48 \mathrm{hr} \mathrm{LC}_{50}$ value of Glyphosate was $42 \mathrm{ppm}$ to D. magna [49]. A group of scientists has reported almost five times for the same species higher at $48 \mathrm{hr} \mathrm{LC}_{50}(250 \mathrm{ppm})$ [50]. A researcher also reported that fish and aquatic invertebrates were more sensitive to Glyphosate than terrestrial organisms [51]. The $\mathrm{LC}_{50}$ values observed in the present investigation for Artemia 24hr old nauplii (instar I) exposed against Malathion and Glyphosate were comparatively lower, which might be due to differences in experimental conditions and sensitivity of the species. Toxicity of a xenobiotic is governed by many factors, such as water temperature, purity of the toxin, life stage of organism, size of the individual etc.

From the results, it was clear that Artemia sp. is more sensitive to the exposure of the organophosphate Glyphosate than that of Malathion. The residues of organophosphate can be easily accumulated in the tissues of Artemia either by direct contact or by ingestion and the secondary effects might be observable in predators of Artemia in aquatic environments [31]. In conclusion, the branchiopod microcrustacean Artemia proved to be an excellent ecotoxicological bioindicator for marine and saline environments polluted with organophosphate residues and may be considered as an important bio monitoring tool for future toxicological analysis.

\section{ACKNOWLEDGEMENTS}

We thank the Management, Principal and HOD (Zoology), The New College (Autonomous), Chennai- 14 for providing necessary facilities.

\section{REFERENCES}

[1] Begum, G. 2004. Carbofuran insecticide induced biochemical alterations in liver and muscle tissues of the fish Clarias batrachus (Linn) and recovery response. Aquatic Toxicology, 66, 83-92.

[2] Arun Kumar, M.S., Jawahar, A.A. 2014b. Effect of two organophosphorus pesticides on the reproductive bionomics of freshwater fairy shrimp Streptocephalus dichotomus (Baird, 1860)

[7] Manna, G.K., Mukherjee, P.K. 1986. Effect of organophosphate insecticide 'Malathion' on chromosome cell division and total muscle proteins of cichilid fish, Tilapia, in: G.K. Manna, S.C. Roy (Eds.), Proceedings of the Xth All India Congress on Cytol. Gene., Kalyani, West Bengal, 7-10 October, Pers. Cytol. Genet. 5, 225-235.

[8] Porte, C., Barceló, D., Tavares, T.M., Rocha, V.C., Albaiges. J. 1990. The use of the mussel watches and molecular marker concepts in studies of hydrocarbon in a tropical bay (Todos os Santos. Bahia, Brazil). Archives of Environmental Contamination and Toxicology, 19, 263-274.

[9] Yeh, S.P., Sung, T.G., Chang, C., Cheng, W., Kuo, C.M. 2005. Effects of an organophosphorus insecticide, Trichlorfon, on hematological parameters of the giant freshwater prawn, Macrobrachium rosenbergii (de Man). Aquaculture, 243, 383-392.

[10] Feng, T., Li, Z.B., Guo, X.Q., Guo, J.P. 2007. Effects of Trichlorfon and Sodium dodecyl sulfate on antioxidant defense system and acetylcholinesterase of Tilapia nilotica in vitro. Pesticide Biochemistry and Physiology, 92, 107-113.

[11] Yonar, M.E., Sakin, F. 2011. Ameliorative effect of lycopene on antioxidant status in Cyprinus carpio during Pyrethroid Deltamethrin exposure. Pesticide Biochemistry and Physiology, 99, 226-231.

[12] Chang, C.C., Rahmawaty, A., Chang, Z.W. 2013. Molecular and immunological responses of the giant prawn. Macrobrachium rosenbergii, to the organophosphorus insecticide, Trichlorfon. Aquatic Toxicology, $130-131,18-26$.

[13] Lavarias, S., García, F., Crespo, R., Pedrini, N., Heras, H. 2013. Study of biochemical biomarkers in freshwater prawn Macrobrachium borellii (Crustacea: Palaemonidae) exposed to organophosphate Fenitrothion. Ecotoxicology and Environmental Safety, 96, 10-16.

[14] Sarma, S.S.S., Nandini, S. 2007. Review of recent Ecotoxicological studies on cladocerans Journal. Environmental Science and Technology, 41 (17), 6124-6128.

[15] Nikam, S.M., Shejule, K.B., Patil, R.B. 2011. Study of acute toxicity of Metasystox on the freshwater fish Nemacheilus botia, from Kedrai dam in Maharashtra, India. Biology and Medicine, 3 (4), 13-17.

[16] Arun Kumar, M.S., Jawahar, A.A. 2014a. Histopathological changes in the Ovaries and Muscle tissues of freshwater Fairy shrimp Streptocephalus dichotomus (Baird, 1860), exposed to Malathion and Glyphosate. International Journal of Bioassays, 3 (09), 3229-3232.

[17] Krishnapriya, R., Padmaja, M. 2014. Study on individual and combined toxicity of Quinalphos and Dimethoate on certain neurological aspects of giant freshwater prawn Macrobrachium rosenbergii (Deman, 1879). International Journal of Science and Research, 4 (5), 1-5.

[18] Robinson, C.B., Samocha, T.M., Fox, Gandy, R.L., McKee, D.A. 2005. The use of inert artificial commercial food sources as replacements of traditional live food items in the culture of larval shrimp, Farfantepenaeus aztecus. Aquaculture, 245, 135-147.

[19] Tlusty, M.F., Jason, S., Goldstein, Fiore, D.R. 2005. Hatchery performance of early benthic juvenile American lobsters (Homarus 
americanus) fed enriched frozen adult Artemia diets. Aquaculture Nutrition, 11, 191-198.

[20] Holme, M.H., Zeng, C., Southgate, P.C. 2006. Use of microbound diets for larval culture of the mud crab, Scylla serrate. Aquaculture, 257, 482490.

[21] Johnston, M.D., Johnston, D.J., Jones, C.M. 2008. Evaluation of partial replacement of live and fresh feeds with a formulated diet and the influence of weaning Panulirus ornatus phyllosomata onto a formulated diet during early ontogeny. Aquaculture International, 16, 33-47.

[22] Gamboa-Delgado, J., Le Vay, L. 2009. Artemia replacement in cofeeding regimes for mysis and postlarval stages of Litopenaeus vannamei: nutritional contribution of inert diets to tissue growth as indicated by natural carbon stable isotopes. Aquaculture, 297, 128-135.

[23] Demeny, F., Trenovszki, M.M., Varga, S., Hegyi, A., Urbanyi, B., Zarski, D., Acs, B., Miljanovic, B., Specziar, A., Muller, T. 2012. Relative efficiencies of Artemia nauplii, dry food and mixed food diets in intensive rearing of larval Crucian carp (Carassius carassius L.). TRJAS, 12, 691-698.

[24] Bhavan, S.P., Kavithamani, N., Radhakrishnan, S., Muralisankar, T., Srinivasan, V., Manickam, N. 2013. Comparison of nutritional quality of sunflower oil and cod liver oil enriched with Artemia nauplii for assessing their efficacies on growth of the prawn Macrobrachium rosenbergii post larva. International Journal of Current Science, 7, E 67-79.

[25] Cobo, M.L., Wouters, R., Wille, M., Sonnenholzner, S., Sorgeloos, P. 2014. Evaluation of frozen umbrella stage Artemia as first animal live food for Litopeneaeus vannamei (Boone) Larvae. Aquaculture Research, 1-8.

[26] Persoone, G., Vell, V.D., Steergem, M.A.V., Nayer, B. 1989. Predictive value for the laboratory test with aquatic invertebrates. Influence of experimental condition. Aquatic Toxicology, 14, 149-166.

[27] Ali, J., Janseen, R.C., Persoone, G. 1991. Development of a costeffective acute toxicity screening test to determine the toxicity of coatings on submerged structures. In: Book of abstracts. SETAC-Europe Founding Conference- Environmental sciences and sustainable development. Sheffied, U.K.

[28] Ali, J.A., Govindaraj, A. 2005. Toxicity of antifouling paint to selected Zooplankton. Pollution Research, 24, 211-216.

[29] Krishnakumar, P.K., Dineshbabu, A.P., Sasikumar, G., Bhat, G.S. 2007. Toxicity evaluation of treated refinery effluent using brine shrimp (Artemia salina) egg and larval bioassay. Fishery Technology, 44 (1), 8592.

[30] Varo, I., Amat, F., Navarro, J., Barreda, M., Serrano, R., Hernandez, F 2003. Exposure of Artemia sp. (Crustacea) cysts to the organophoshorus pesticide Chlorpyrifos. Efficacy of the chorion as barrier. CICTA, PortoPortugal.

[31] Obregon, E.B., Vargas, A. 2010. Chronic toxicity bioassay with populations of the crustacean Artemia salina exposed to the organophosphate Diazinon. Biological Research, 43, 357-362.

[32] Finney, D.J. 1964. Probit Analysis, 2nd Edn. Cambridge university press, London.

[33] George, D., Mallery, P. 2006. SPSS for windows Step by Step a Simple Guide and Reference 13.0 update sixth Edition Pearson Education, Inc.

[34] Gajbhiye, S.N., Hirota, R. 1990. Toxicity of heavy metals to brine shrimp Artemia. Journal of Indian Fisheries Association, 20, 43-50.

[35] Varo, I., Taylor, A.C., Ferrando, M.D., Amat, F. 1997. Effect of Endosufan pesticide on the oxygen consumption rates of nauplii of different Spanish strains of Artemia. Journal of Environmental Science and Health, Part B, 32, 363-375

[36] Hadjispyrou, S., Kungolos, A., Anagnostopoulos, A. 2001. Toxicity bioaccumulation, and interactive effects of Organotin, Cadmium, and Chromium on Artermia franciscana. Ecotoxicology and Environmental Safety, 49, 179-186.

[37] Varo, I., Navarro, J.C., Amat, F., Guilhermino, L. 2002 Characterization of cholinesterases and evaluation of the inhibitory potential of Chlorpyrifos and Dichlorvos to Artemia salina and Artemia parthenogenetica. Chemosphere, 48, 563-569.

[38] Brix, K.V., Cardwell, R.D., Adams, W.J. 2003. Chronic toxicity of arsenic to the Great Salt Lake brine shrimp, Artemia franciscana. Ecotoxicology and Environmental Safety, 54, 169-175.

[39] Falis, M., Spalkova, M., Legath, J. 2014. Effects of heavy metals and pesticides on survival of Artemia franciscana. Acta Veterinaria Brno, 83, 95-99.

[40] Bengtson, D.A., Léger, P., Sorgeloos, P. 1991. Use of Artemia as a food source for aquaculture. In R. A. Browne, P. Sorgeloos and C.N.A. Trotman (eds.), Artemia Biology, CRC Press, Boca Raton, Florida, pp. 255-285.

[41] Crisinel, A., Delaunay, D., Rossel, J., Tarradellas, H., Meye, H., Saiah, P., Vogel, C., Delisle, Blaise, C. 1994. Cyst based ecotoxicological tests using anostracans: Comparison of two species of Streptocephalus. Environmental Toxicology and Water Quality, 9, 317-326.

[42] Lahr, J.A., Badji, S., Marquenine, E., Schuiling, K.B., Ndour, Diallo, O., Everts, J.W. 2001. Acute toxicity of Locust insecticides to two indigenous invertebrates from sahelian temporary ponds. Ecotoxicology and Environmental Safety, 48, 66-75.

[43] Verschueren, K. 2001. Hand book of Environmental Data on organic chemicals, fourth edition. John Wiley \& sons, New York.

[44] Ripley, B.J., Davis, K.C., Carter, B.J., Simovich, M. 2003. Toxicity of Malathion and Roundup to the San Diego fairy shrimp. The Western Section of the Wildlife Society, 38 (39), 13-21.

[45] Sidharta, R.B. 1997. Effects of Malathion on Brine shrimp (Artemia salina L.). A preliminary lethal toxicity test. Biota, 11 (2), 61-66.

[46] Nelson, S., Roline, R.A. 1998. Evaluation of sensitivity of rapid toxicity tests relative to daphnid acute lethality tests. Bulletin of Environmental Contamination and Toxicology, 60, 292-299.

[47] Rassoulzadegan, M., Akyurtlakli, N. 2002. An investigation on the toxic effects of Malathion organophosphate insecticide on the Daphnia magna Straus, 1820 (Crustacea: Cladocera). Turkish Journal of Zoology, $26,349-355$.

[48] Fochtman, P.A., Raszka, Nierzedska. 2000. The use of conventional bioassays, microbiotests, and some "rapid" methods in the selection of an optimal test battery for the assessment of pesticides toxicity. Environmental Toxicology, 15, 376-384.

[49] Alberdi, J.L., Saenz, M.E., Dimarzio, W.D., Trotorelli, M.C. 1996 Comparative Acute toxicity of two Herbicides, Paraquat and Glyphosate, to Daphnia magna and D. spinulata. Bulletin of Environmental Contamination and Toxicology, 57 (2), 229-235.

[50] Raipulis, J., Toma, M.M., Balode, M. 2009. Toxicity and genotoxicity testing of roundup proceedings of the Lat. Proceedings of the National Academy of Sciences, India Section B, (63), 29-32.

[51] Cox, C. 2000. Glyphosate factsheet. J Pestic Reform 108: 3. Available at: http://www.mindfully.org/Pesticide/Roundup-Glyphosate-FactsheetCox.htm. 